\title{
Analisis Efisiensi Usaha dan Nilai Tambah Agroindustri Olahan di Kota Mataram
}

\author{
Suprianto*, Lukman Hakim, dan Sujadi \\ Fakultas Ekonomi dan Bisnis Universitas Mataram
}

Corresponding email: pithikngguyu@gmail.com

\begin{tabular}{|c|c|}
\hline Info Artikel & ABSTRAK \\
\hline $\begin{array}{l}\text { Kata Kunci: } \\
\text { Efisiensi Usaha, Nilai } \\
\text { Tambah }\end{array}$ & $\begin{array}{l}\text { Tujuan dari penelitian ini untuk menganalisis biaya produksi dan tingkat } \\
\text { pendapatan, efisiensi usaha dan besarnya Nilai tambah atau Rasio Nilai Tambah } \\
\text { (RNT). Penelitian ini dilakukan dengan mengambil tiga unit usaha yaitu usaha } \\
\text { industri pengolahan kerupuk kulit,usaha industri pengolahan tempe dan usaha } \\
\text { industri pengolahan tahu yang ditentukan secara purposive. } \\
\text { Secara keseluruhan dari ketiga unit usaha agroindustri pengolahan dimana } \\
\text { tingkat rasio usahanya (R/C Rasionya ) rata-rata diatas } 1 \text { atau R/C Rasio nya }>1 \\
\text { artinya bahwa baik usaha industri kerupuk kulit (R/C Rasio }=1,78 \text { ) dan usaha } \\
\text { industri tempe ( R/C Rasio }=1,43 \text { ), dan usaha industri tahu (R/C Rasio = } 1,47 \text { ) } \\
\text { ketiganya menguntungkan untuk diusahakan, dengan pendapatan masing-masing } \\
\text { diperoleh industri kerupuk kulit sebesar Rp } 3.254 .750,- \text { dan industri tempe Rp } \\
\text { 351.625,33, dan industri tahu Rp } 340.000 \text {,- dalam sekali proses produksi. } \\
\text { Nilai Tambah usaha industri pengolahan kerupuk kulit sebesar Rp } \\
\text { 54.641,79 dengan Rasio Nilai Tambah (RNT) sebesar } 50,53 \% \text { hal ini berarti } \\
\text { bahwa nilai tambahnya tergolong tinggi karena RNT }>50 \% \text {. Selanjutnya Nilai } \\
\text { Tambah usaha industri pengolahan tempe sebesar Rp } 346.625,- \text { dengan tingka } \\
\text { Rasio Nilai Tambah sebesar } 30,15 \% \text { berarti bahwa usaha agroindustri pengolahan } \\
\text { tempe nilai tambahnya tergolong rendah karena RNT }<50 \% \text {. Dan Nilai Tambah } \\
\text { usaha industri pengolahan tahu sebesar Rp } 440.083,31 \text { dengan tingkat Rasio Nilai } \\
\text { Tambah sebesar } 41,49 \% \text {, berarti usaha agroindustri pengolahan tahu nilai } \\
\text { tambahnya masih rendah ( RNT }<50 \% \text { ). } \\
\text { Untuk lebih meningkatkan nilai tambah dari ketiga jenis usaha agroindustri } \\
\text { pengolahan (usaha kerupuk kulit sapi, usaha tempe dan usaha tahu ) hendaknya } \\
\text { lebih menekan biaya operasional seperti penggunaan bahan bakar, pemakaian } \\
\text { listrik, pembelian bahan penolong. Selain itu perlu inovasi baru dalam menciptakan } \\
\text { produk-produk baru yang lebih menarik daya beli konsumen. }\end{array}$ \\
\hline
\end{tabular}

\section{ABSTRACT}

\section{PENDAHULUAN \\ a. Latar Belakang}

Pengembangan agroindustri merupakan keharusan dalam rangka menuju masyarakat industri yang berbasis pertanian, baik agroindustri berskala besar maupun agroindustri berskala kecil seperti agroindustri rumah tangga. Agribisnis dan agroindustri dua kegiatan usaha dibidang pertanian yang mampu menaikkan pendapatan masyarakat baik dipedesaan maupun diperkotaan serta dapat menampung tenaga kerja non skill yang cukup besar. Menurut Midayanto (2014) mendifinisikan agroindustri dalam dua hal, yaitu pertama agroindustri sebagai industri yang berbahan baku utama 


\section{Elastisitas - Jurnal Ekonomi Pembangunan}

Vol. 2 No. 1, Maret 2020

dari produk pertanian dan kedua agroindustri sebagai suatu tahapan pembangunan sebagai kelanjutan dari pembangunan pertanian tetapi sebelum tahapan pembangunan tersebut mencapai tahapan tahapan pembangunan industri.

Kegiatan agroindustri ini umumnya melibatkan usaha kecil dan menengah yang merupakan kegiatan ekonomi rakyat yang berskala kecil dengan berbagai kekurangan dan kendala yang dimilki oleh kelompok usaha kecil dan menengah ini. Namun pengalaman menunjukkan bahwa usaha kecil atau industri kecil dan menengah memiliki ketangguhan terhadap goncangan perekonomian global, disamping itu jugan industri kecil dan menengah memiloiki kemampuan yang cukup besr untuk menyediakan lapangan pekerjaan, membuka peluang usaha, menyerap tenaga kerja serta memberi pendapatan kepada masyarakat untuk menjamin kehidupan yang lebih sejahtera.

Nusa Tenggara Barat sebagai salah satu daerah penyangga pangan nasional yang berbasis pada pengembangan sektor pertaanian khususnya tanaman padi, palawija,sayuran, umbi umbian dan hasil ternak memiliki potensi yang cukup besar dalam pengembangan agribisnis dan agroindustri pengolahan input pertanian. Hasil olahan dari input pertanian ini disamping dapat memenuhi kebutuhan masyarakat lokal dan juga untuk memenuhi permintaan dari daerah lain termasuk dalam menunjang kegiatan sektor pariwiswata dalam bentuk wisata kuliner dan oleh-oleh produk makanan khas NTB.Khususnya di kota Mataram sebagai pusat pemerintahan dan perdagangan terdapat berbagai industri kecil dan menengah yang bergerak diberbagai bidang pengolahan input pertanian salah satunya adalah industri pengolah bahan makanan. Data yang kami liris dari kantor Dinas Perindustrian kota Mataram memuat beberapa klaster industri kecil unggulan tersebar dI wilayah kota Mataram yaitu sebagai berikut :

Tabel 1. Klaster industri unggulan di kota Mataram tahun 2017

\begin{tabular}{|l|l|l|r|}
\hline No & \multicolumn{1}{|c|}{ Jenis Industri } & Wilayah Pengembangan & Jumlah Usaha \\
\hline 1 & Kerajinan Mutiara Emas dan Perak & Sekabela dan Kamasan & 224 \\
\hline 2 & Kerupuk Kulit & Seganteng & 9 \\
\hline 3 & Tahu dan Tempe & AbianTubuh & 66 \\
& & Kekalik Grisak & 227 \\
\hline 4 & Industri Kerajinan Logam & Babakan & 8 \\
\hline 5 & Kerajinan Kayu dan Cukli & Sayang-Sayang & 25 \\
\hline 6 & Konveksi dan Bordir & Pagutan & 17 \\
\hline 7 & Kerajinan Kulit kerang dan Tanduk & Pagutan & - \\
\hline 8 & Makanan Olahan & 6 Kecamatan & 990 \\
\hline
\end{tabular}

Sumber : Dinas Perindustrian Kota Mataram

Dari tampilan data di atas sebagian besar industri pengolahan bahan makanan yang berkembang di kota mataram kemudian industri tahu dan tempe yang berada diwilayah abian tubuh dan kekalik grisak sebagai sentra pengolahan bahan baku kedelai untuk diolah menjadi produk Tahu dan Tempe walaupun harga input kedelai mengalami kenaikan usaha ini masih tetap berjalan. Selanjutnya usaha kerajinan mutiara emas dan perak sebagai produk oleh-oleh yang cukup dikenal masyarakat luar daerah NTB dengan mutiaranya yang ada di sekarbeloa, kemudia industri logam, konveksi danindustri kerupuk kulit yang jumlahnya masih sedikit dan perlu untuk dikembangkan kedepannya. 


\section{Elastisitas - Jurnal Ekonomi Pembangunan}

Vol. 2 No. 1, Maret 2020

Industri kecil dikota Mataram sebagian besar memiliki kedekatan secara ekonomi dan sosial dengan masyarakat petani karena input bahannya berasal dari hasil-hasil pertanian seperti kedelai untuk kebutuhan agroindustri tahu dan tempe, umbi-umbian untuk usaha keripik singkong, kerupuk kulit dan dodol nangka. Kebutuhan akan bahan baku untuk memenuhi usaha agroindustri cukup besar dan pasokannya harus tetap tersedia dipasaran. Sampai sejauhmana produk usaha agroindustri unggulan ini dapat memenurhi permintaan konsumen dengan semakin bertambahnya penduduk diperkotaan , maka perlu dilakukan penelitian tentang “ Analisis Efisiensi usaha Dan Nilai Tambah produk agroindustri olahan di Kota Mataram.

\section{b. Tujuan Penelitian}

1) Menganalisis seberapa besar produk yang dihasilkan dapat memberi keuntungan bagi pengusaha agroindustri olahan di kota Mataram

2) Menganalisis apakah usaha agroindustri olahan ini layak untuk dikembangkan atau tidak jika dilihat dari $\mathrm{B} / \mathrm{C}$ ratio nya.

3) Menganalisis tingkat nilai tambah dari produk agroindustri olahan dalam sekali proses produksi

\section{METODE PENELITIAN}

a. Jenis Penelitian

Jenis penelitian yang digunakan adalah penelitian deskriptif, yaitu suatu metode yang dijalankan dalam penelitian terhadap status kelompok manusia, suatu obyek ,suatu set kondisi ,suatu sistem pemikiran ataupun suatu kelas peristiwa pada masa sekarang. Penelitian ini bertujuan untuk membuat gambaran atau lukisan secara sistematis, faktual dan akurat mengenai kondisi pengusaha agroindustri olahan di kota Mataram.

\section{b. Tempat dan Waktu Penelitian}

Penelitian ini dilaksanakan di kota Mataram dengan mengambil lokasi di pondokperasi ampenan, Kekalik Grisak yaitu Kelurahan Kekalik Jaya dan Abiantubuh Kelurahan Cakranegara dan Seganteng . Obyek dalam penelitian ini adalah pengusaha agroindustri olahan yang ada di kota Mataram yaitu Usaha kerupuk Kulit di Seganteng, Usaha industri pengolahan Tahu di Abiantubuh dan usaha industri pengolahan tempe di Kekalik Mataram .

\section{c. Jenis Data}

Penelitian ini menggunakan data primer dan data sekunder sebagai pendukung analisis. Data primer yang diambil dalam penelitian ini adalah meliputi identitas responden, data produksi, biaya produksi, bahan baku kedelai, tenaga kerja , bahan bakar dan lain-lain. Sedangkan data sekunder diperoleh dari instansi yang terkait seperti jumlah industri kecil di kota Mataram serta publikasi yang ada kaitannya dengan penelitian .

\section{d. Teknik Pengumpulan Data}

Teknik pengumpulan data dilakukan dengan metode survey yaitu dengan mendata langsung perusahaan agroindustri olahan sesuai dengan kebutuhan analisis yaitu ditentukan sampel sebanyak 3 unit usaha agroindustri olahan secara purposive, yaitu 1 pengusaha tempe yang berada dilokasi kekalik Grisak Kelurahan Kekalik jaya dan 1 pengusaha tahu di abian tubuh Cakranegara, 1 usaha industri kerupuk kulit di Seganteng .

\section{e. Analisis Data}

Data-data yang dikumpulkan dalam penelitian ini akan dianalisis secara kualitatif dan kuantitatif . Penggunaan ananalisis kualitatif untuk mendapatkan gambaran kondisi riil usaha agroindustri olahan dilokasi penelitian. Sedangkan data kuantitatif digunakan untuk menganalisis tingkat efisiensi usaha dan perhitungan biaya produksi dan nilai tambah dalam penelitian ini antara lain :

1) Analisis Penyusutan Peralatan 


\section{Elastisitas - Jurnal Ekonomi Pembangunan}

Vol. 2 No. 1, Maret 2020

Biaya penyusutan peralatan produksi dihitung dengan menggunakan Metode Garis Lurus dengan rumus sebagai berikut :

$\mathrm{D}=\mathrm{P}-\mathrm{S} / \mathrm{N}$

Dimana :

$\mathrm{D}=$ Biaya penyusutan peralatan per tahun

$\mathrm{P}=$ Harga awal peralatan $(\mathrm{Rp})$

$\mathrm{S}=$ Harga Akhir peralatan (Rp)

$\mathrm{N}=$ Perkiraan Umur ekonomis (tahun)

2) Analisis Biaya Produksi

Biaya produksi merupakan penjumlahan biaya tetap dan biaya variabel. Besarnya biaya produksi dihitung dengan persamaan berikut :

$\mathrm{BP}=\mathrm{BT}+\mathrm{BV}$

Dimana :

$\mathrm{BP}=$ Biaya Produksi (Rp/tahun)

$\mathrm{BT}=$ Biaya tetap $(\mathrm{Rp} /$ tahun $)$

$\mathrm{BV}=$ Biaya Variabel (Rp/tahun)

3) Analisis Penerimaan (Revenue)

Penerimaan Total atau total Revenue dari usaha agroindustri olahan dapat diperoleh dari hasil perankalian antara jumlah produksi tahu yang dihasilkan dikalikan dengan harga tahu, atau secara matematis dapat di tulis :

$$
\mathrm{TR}=\mathrm{P} \times \mathrm{Q}
$$

Dimana :

$\mathrm{TR}=$ Total Revenue (total penerimaan $\mathrm{Rp} /$ tahun)

$\mathrm{Q}=$ Kuantitas $(\mathrm{kg})$

$\mathrm{P} \quad=$ Harga tahu per kilogram $(\mathrm{Rp})$

Keuntungan dihitung dengan rumus :

$\pi=\mathrm{TR}-\mathrm{TC}$

Dimana :

$\Pi=$ Keuntungan usaha industri pengolahan

$\mathrm{TR}=$ Total Penerimaan kotor

$\mathrm{TC}=$ Total Biaya produksi
4) Analisis efisiensi Usaha

Perhitungan efisiensi usaha agroindustri yang digunakan adalah Revenue Cost Ratio (R/C Ratio). Menurut Soekartawi (2005) R/C Ratio adalah perbandingan antara total penerimaan dengan total biaya yang menunjukkan nilai penerimaan yang diperoleh dari setiap rupiah yang dikeluarkan. Secara matematis dapat dirumuskan sebagai berikut :

$\mathrm{R} / \mathrm{C}=$ Total Penerimaan $(\mathrm{TR}) /$ Total Biaya (TC)

Dimana :

a) Jika $\mathrm{R} / \mathrm{C}>1$, maka Usaha agroindustri pengolahan menguntungkan untuk diusahakan

b) Jika $\mathrm{R} / \mathrm{C}<1$, maka usaha agroindustri pengolahan tidak layak untuk diusahakan (merugi ).

c) Jika $\mathrm{R} / \mathrm{C}=1$, maka usaha agroindustrki pengolahan dalam posisi tidak untung dan tidak merugi (mencapai titik impas )

5) Analisis Nilai Tambah dengan rumus sebagai berikut ( Sudiyono ; 2004 )

$\mathrm{NTp}=\mathrm{Na}-\mathrm{Ba}$

$\mathrm{Ba}=(\mathrm{Bb}+\mathrm{Bp}+\mathrm{Bbp})$

Keterangan :

NTp $=$ Nilai Tambah Produk $(\mathrm{Rp})$

$\mathrm{Na}=$ Nilai Produk Akhir $(\mathrm{Rp})$

$\mathrm{Ba}=$ Biaya antara $(\mathrm{Rp})$

$\mathrm{Bb}=$ Biaya bahan baku (Rp)

$\mathrm{Bp}=$ Biaya penyusutan alat $(\mathrm{Rp})$

Bbp = Biaya bahan penolong $(\mathrm{Rp})$

Rasio Nilai Tambah $($ RNT $)=$ NT $/$ NP

Dimana : RNT = Rasio nilai tambah (\%)

NT = Nilai Tambah $(\mathrm{Rp})$

$\mathrm{NP}=$ Nilai Produksi ( Rp ).

Keterangan :

a. Jika Rasio Nilai Tambah $>50 \%$, maka nilai tambah produk olahan tinggi 


\section{Elastisitas - Jurnal Ekonomi Pembangunan}

Vol. 2 No. 1, Maret 2020

b. Jika Rasio Nilai Tambah $<50 \%$, maka nilai tambah produk olahan rendah

\section{HASIL DAN PEMBAHASAN}

\section{a. Gambaran Umum Agroindustri} Pengolahan

Agroindustri sebagai salah satu sub sistem penting dalam sistem agribisnis sangat berperan di dalam menggerak perekonomian di daerah perkotaan maupun pedesaan.

Keduanya sangat berperan dalam kegiatan ekonomi dalam rangka untuk mendorong pertumbuhan ekonomi yang tinggi karena produk produk yang dihasilksn dari agro industri pengolahan memiliki pangsa pasar yang luas dan memberikan nilai tambah yang relatif tinggi dalam produk nasional. Disisi lain dikemukakan oleh Saragih (2001) bahwa agroindustri juga dapat menjadi wahana bagi usaha untuk $\mathrm{m}$,engatasi kemiskinan karena daya jangkau dan spektrum kegiatannya yang sangat luas dan beragam bentuknya.

Ciri-ciri agroindustri pengolahan hasil pertanian sebagai berikut (Soekartawi; 1998):

1) Dapat meningkatkan nilai tambah

2) Menghasilkan produk yang dapat dipasarkan atau digunakan atau dimakan

3) Meningkatkan daya saing, dan

4) Menambah pendapatan dan keuntungan produsen

Melalui proses pengolahan berbagai input bahan baku produksi pertanian ini akan lebih beragam kegunaannya.

Di kota Mataram keberadaan agroindustri pengolahan berkembang cukup pesat, hal ini dapat kita lihat dari banyaknya dan beragamnya produk produk makanan olahan yang dapat digunakan oleh konsumen maupun untuk dikonsumsi langsung berupa makanan olahan siap saji maupun berupa makanan camilan seperti kerupuk dan lain sebagainya. Produk-produk yang dihasilkan merupakan produk yang sifatnya umum maupun produk yang spesifik lokal, seperti kerupuk kulit, tahu, tempe, ikan pindang, dodol nangka, roti atau kue-kue basah maupun kering, olahan rumput laut danlain sebagainya. Produk olahan lokal biasanya banyak peminatnya dan dicari oleh pem,beli sebagaoi makanan seharihari maupun untuk oleh-oleh khas lombok bagi mayarakat atau tamu maupun woisatawan yang berkunjung ke Mataram.

Aneka ragam produk olahan ini menjadi daya tarik bagi kedatangan wisatawan ke pulau lombok untuk menikmati wisata kuliner khas Lombok. Hal ini secara tidak langsung akan memberi dampak terhadap mayarakat yang berkecimpung di dunia bisnis makanan olahan dan ini akan memberi nilai tambah berupa pendapatan yang diterima oleh mereka yang usahanya bergerak dalam bidang agroindustri pengolahan makanan. Sektor industri pengolahan ini baik sebagai penyangga sektor pariwisata juga dalam rangka untuk menciptakan peluang kerja bagi masyarakat kota Mataram. Hal ini ditunjang dengan semakin membaiknya perekonomian kota Mataram pasca gempa bumi 2018 akan meningkatkan dunia usaha khususnya usaha makanan olahan, disisi lain dengan perbaikan ekonomi ini akan meningkatkan daya beli masyarakat utnuk berbelanja produk-produk olahan yang ditawarkan dengan tingkat harga yang terjangkau.

\section{b. Proses Produksi}

Proses produksi adalah bagaimana bahan baku diolah atau diproses melalui berbagai macam cara sehingga menghasilkan produk olahan yang siap dikonsumsi. Proses produksi yang dilakukan masing-masing komoditi bahan baku metode dan cara pengolahannya berbeda beda satu dengan yang lainnya dan ini semua tergsantung dari produk yang di hasilkan. Namun secara umum proses produksi yang dilakukan oleh pengusaha agroindustri olahan ini masih sederhana serta kalaupun ada mereka mengkombinasikan metode tradisional dengan teknologi, namun jumlahnya tidak banyak dan umumnya mereka bekerja masih secara tradisional. Tenaga kerja yang terlibat dalam proses produksi juga melibatkan tenaga kerja keluarga disamping juga tenaga kerja di 


\section{Elastisitas - Jurnal Ekonomi Pembangunan}

Vol. 2 No. 1, Maret 2020

luar keluarga dengan sistem pengupahan ada yang harian, borongan, atau diupah perunit produk.

\section{c. Proses Produksi Kerupuk Kulit Sapi}

1) Jenis Peralatan Dan Nilai Penyusutan Peralatan

Penggunaan peralatan dalam proses produksi sangat berperan dalam kegiatan selama dalam proses produksi. Penggunaan peralatan yang tepat akan membantu memudahkan jalannya proses kegiatan produksi. Peralatan yang digunakan terdiri dari berbagai macam jenisnya tergantung dari olahan produk yang dihasilkan dan harga dari masing-masing jenis peralatan juga berbeda. Nilai peralatan yang digunakan nantinya akan dihitung untuk memperoleh nilai penyusutan peralatan dengan melihat umur ekonomis dari peralatan yang digunakan. Berikut nilai penyusutan peralatan dari berbagai produk olahan agroindustri .

Tabel 1. Jenis Peralatan dan Biaya Penyusutan Pada Industri Pengolahan Kerupuk Kulit Sapi UD. Shinta di Seganteng

\begin{tabular}{|l|c|}
\hline Jenis Alat & Penyusutan (Rp)/pp \\
\hline Talenan & 5.000 \\
\hline Wajan besar & 11.667 \\
\hline Pisau & 5.000 \\
\hline Parang & 4.500 \\
\hline Keranjang & 7.500 \\
\hline Ember & 10.000 \\
\hline Bambo & 10.000 \\
\hline Asah besar & 8.333 \\
\hline Asah kecil & 3.750 \\
\hline Gergaji besi & 6.250 \\
\hline Scaler & 19.167 \\
\hline Timbangan gantung & 11.667 \\
\hline Timbangan duduk & 10.417 \\
\hline Total Biaya & 113.251 \\
\hline
\end{tabular}

Pengusaha kerupuk kulit dalam proses produksinya menggunakan bahan baku dan bahan penolong.Dalam proses produksi agroindustri olahan kerupuk kulit terdiri dari bahan baku utamanya kulit sapi , dan bahanbahan penolong lainnya seperti garam, bawang putih, minyak goreng, masako, gas LPG, plastik pembungkus.

Tabel 2. Jenis Biaya bahan selama sekali proses produksi Kerupuk Kulit Sapi

\begin{tabular}{|c|l|r|r|r|}
\hline No & \multicolumn{1}{|c|}{ Jenis Bahan } & Jumlah Unit & \multicolumn{1}{c|}{$\begin{array}{c}\text { Harga Satuan } \\
\text { (Rp) }\end{array}$} & \multicolumn{1}{c|}{$\begin{array}{c}\text { Total Biaya } \\
\text { (Rp) }\end{array}$} \\
\hline 1 & Bahan Utama: & $100 \mathrm{Kg}$ & 27.000 & 2.700 .000 \\
& Kulit Sapi & & & \\
\hline 2 & Bahan Penolong: & $1 \mathrm{Kg}$ & 10.000 & 10.000 \\
& - Garam & $8 \mathrm{bks}$ & 500 & 4.000 \\
& - Masako & $5 \mathrm{Kg}$ & 30.000 & 150.000 \\
& - Bawang puth & $1 / 2 \mathrm{Kg}$ & 40.000 & 20.000 \\
& - Ketumbar & $60 \mathrm{Kg}$ & 9.000 & 540.000 \\
& - Minyak Goreng & $6 \mathrm{bh}$ & 18.000 & 108.000 \\
& - Gas LPG & $1 / 2 \mathrm{bal}$ & 60.000 & 30.000 \\
\hline & - Plastik & & & 3.562 .000 \\
\hline
\end{tabular}

Tabel 2. di atas menggambarkan tentang rincian penggunaan biaya bahan baku utama dan bahan baku penolong yang diperlukan dalam sekali proses produksi agroindustri olahan kerupuk kulit UD. Shinta di Seganteng Cakranegara. Biaya bahan baku yang terbesar disini adalah pembelian bahan baku utama kulit sapi basah sebanyak $100 \mathrm{Kg}$ dengan total harga Rp 2.700.000,-- kemudian biaya pemakaian minyak goreng Rp 540.000, selanjutnya pembelian bawang putih $\mathrm{Rp}$ 150.000 dan biaya terendah pemakaian bumbu masako Rp 4000. Selain biaya bahanbahan baku dan bahan penolong dalam proses 


\section{Elastisitas - Jurnal Ekonomi Pembangunan}

Vol. 2 No. 1, Maret 2020

produksi juga ada biaya tenaga kerja yaitu mulai dari proses pengulitan di upah $\mathrm{Rp}$ 4000/Kg dan biaya pemotongan kulit $\mathrm{Rp}$ 1000/Kg > Jadi dengan bahan baku kulit sebanya $100 \mathrm{Kg}$ maka biaya tenaga kerja yang dikeluarkan sebesar Rp 500.000,- terdiri dari biya pengulitan $\mathrm{Rp} 400.000$ dan biaya pemotongan sebesar Rp 100.000 .

Tabel 3. Penerimaan Hasil Penjualan Kerupuk Kulit UD. Shinta di Seganteng

\begin{tabular}{|l|c|c|c|}
\hline \multicolumn{1}{|c|}{ Ukuran Produk } & Jumlah Satuan & $\begin{array}{c}\text { Harga jual Satuan } \\
\text { ( Rp ) }\end{array}$ & $\begin{array}{c}\text { Nilai Produksi } \\
\text { ( Rp ) }\end{array}$ \\
\hline 1 ball 3 Kg Biasa & 20 ball & 300.000 & 6.000 .000 \\
\hline $1 \mathrm{Kg}$ tipis & $2 \mathrm{Kg}$ & 260.000 & 520.000 \\
\hline ! Kg Stik & $2 \mathrm{Kg}$ & 260.000 & 520.000 \\
\hline $1 \mathrm{Kg}$ setengah matang & $3 \mathrm{Kg}$ & 130.000 & 390.000 \\
\hline Total Penerimaan (TR) & $67 \mathrm{Kg}$ & & 7.430 .000 \\
\hline
\end{tabular}

Tabel 3. Menggambarkan jenis produksi kerupuk yang dihasilkan dalam sekali proses produksi yaitu terdiri dari kerupuk kulit biasa ukuran 1 ball $3 \mathrm{Kg}$ dengan niali produksi $\mathrm{Rp}$ 6.000.000,- produk kerupuk ukuran tipis Rp 520.000 , ukuran stik Rp 520.000 dan kerupuk kulit setengah matang Rp 390.000,dengan total seluruh penerimaan dalam sekali produksi kerupuk kulit yaitu sebesar Rp 7.430.000,-

\section{A. Pendapatan Pengusaha kerupuk Kulit Sapi}

Dengan demikian maka keuntungan yang dioperoleh pengusaha kerupuk kulit UD. Shanti dalam sekali proses produksi adalah :

$$
\begin{aligned}
\Pi & =\mathrm{TR}-\mathrm{TC} \\
& =7.430 .000-(113.251+3.562 .000+ \\
& 500.000) \\
& =7.430 .000-4.175 .251 \\
& =3.254 .749,-
\end{aligned}
$$

\section{B. Efisiensi Usaha}

Efisiensi usaha kerupuk kulit, dimana perhitungan efisiensi yang digunakan adalah

$\mathrm{R} / \mathrm{C}$ Ratio $=\mathrm{TR} / \mathrm{TC}$

$=7.430 .000 / 4.175 .251$

$=1,78$, Artinya bahwa jika $\mathrm{R} / \mathrm{C}>1$ maka usaha agroindustri kerupuk kulit menguntungkan untuk diusahakan.

\section{Analisis Nilai Tambah :}

Perhitungan seberapa besar nilai tambah yang dihasilkan dari proses agroindustri usaha kerupuk kulit UD. Shinta di Seganteng Cakranegara dilakukan untuk mengetahui besarnya nilai yang ditambahkanpada bahan baku yang digunakan yaitu kulit sapi. Rumus yang digunakan untuk menghitung besarnya nilai tambah adalah :

Tabel 4. Nilai Produksi, Bahan Baku, Bahan penunjang, Nilai Penyusutan Dan Nilai Tambah agroindustri Pengolahan Kerupuk Kulit Sapi

\begin{tabular}{|l|l|r|}
\hline No & \multicolumn{1}{|c|}{ Uraian } & $\begin{array}{c}\text { Nilai ( Rp/Kg) } \\
\text { per proses } \\
\text { produksi }\end{array}$ \\
\hline 1 & Nilai Produksi & 7.430 .000 \\
\hline 2 & $\begin{array}{l}\text { Nilai Bahan Baku } \\
\text { Kedelai }\end{array}$ & 2.700 .000 \\
\hline 3 & Nilai Bahan Penunjang & 862.000 \\
\hline 4 & Nilai Penyusutan & 113.251 \\
\hline $\mathbf{5}$ & Nilai Tambah & $\mathbf{3 . 7 5 4 . 7 4 9}$ \\
\hline $\mathbf{6}$ & Rasio Nilai Tambah & $\mathbf{5 0 , 5 3} \mathbf{( \% )}$ \\
\hline
\end{tabular}

Jadi besarnya Nilai Tambah sekali proses produksi :

$$
\begin{aligned}
\mathrm{NTp} & =\mathrm{Na}-(\mathrm{Bb}+\mathrm{Bp}+\mathrm{Bbp} \\
& =7.430 .000-(2.700 .000+113.251+ \\
& 862.000) \\
& =7.430 .000-3.675 .251 \\
& =3.754 .749
\end{aligned}
$$

Jadi hasil perhitungan nilai tambah usaha kerupuk kulit UD. Shanti sebesar Rp 3.661.000,- ini berarti bahwa untuk besarnya nilai tambah yang ditambahkan pada bahan baku kerupuk kulit sapi diperoleh dari pembagi antara NT dengan total produksi $(\mathrm{Kg})$, yaitu 3.661.000:67 $\mathrm{Kg}=54.641,79$ 


\section{Elastisitas - Jurnal Ekonomi Pembangunan}

Vol. 2 No. 1, Maret 2020

artinya bahwa setiap $1 \mathrm{Kg}$ kulit sapi yang diolah menjadi kerupuk kulit sapi dapat memberikan penambahan nilai sebesar 54.641,79 . Dengan demikian bahwa hasil analisis menunjukkan bahwa usaha agroindustri usaha kerupuk kulit UD. Shinta memiliki prospek yang baik karena usaha kerupuk kulit sapi ini dapat memberikan nilai tambah yang cukup tinggi.

Selanjutnya perhitungan rasio nilai tambah terhadap nilai outputnya yaitu diperoleh dari pembagian antara nilai tambah dengan nilai output yang dinyatakan dalam prosentase (\%). Secara matematis Rasio Nilai Tambah pada industri pengolahan kedelai menjadi produk tempe sebagai berikut :

$$
\begin{aligned}
\text { Rasio Nilai Tambah } & =\mathrm{Rp} \quad 3.754 .749 / \mathrm{Rp} \\
& =50,53 \%
\end{aligned}
$$

Ini berarti Rasio Nilai Tambah produk olahan kulit sapi menjadi kerupuk kulit sapi cukup tinggi , karena Rasionya lebih besar dari ( > $50 \%$ ). Hal ini menunjukkan bahwa apabila hasil perhitungan Rasio Nilai Tambah $>50$ $\%$, ini menunjukkan bahwa nilai tambah yang dihasilkan lebih besar dari nilai outputnya, dan nilai tambahnya tergolong tingi

\section{2) Analisis Usaha Agroindustri Pengolahan Tempe}

Analisis usaha agroindustri pengolahan tempe ini dilakukan untuk melihat seberapa besar nilai produksi yang dihasilkan serta biaya-biaya yang dikeluarkan dalam sekali proses produksi. Hasil analisis ini dapat dipergunakan sebagai pertimbangan apakah nantinya usaha pengolahan tempe ini menguntungkan atau tidak dengan cara menghitung semua biayabiaya yang dikeluarkan dalam proses produksi dan juga untuk mengetahui seberapa besar pendapatan yang diperoleh usaha industri pengolahan tempe.Berikut nilai penyusutan peralatan yang digunakan dalam proses produksi pengolahan kedelai menjadi tempe :

Tabel 5. Biaya Penyusutan Industri Pengolahan Tempe

\begin{tabular}{|l|l|r|}
\hline No & \multicolumn{1}{|c|}{ Jenis Peraltan } & $\begin{array}{c}\text { Nilai Penyusutan } \\
\text { (Rp) }\end{array}$ \\
\hline 1 & Mesin Pemecah Kedelai & $25.000,00$ \\
\hline 2 & Ember & $3.125,00$ \\
\hline 3 & Panci & $15.000,00$ \\
\hline 4 & Bakul & $14,583,00$ \\
\hline 5 & Papan Cetak & $15.000,00$ \\
\hline 6 & Kelabang & $16.666,67$ \\
\hline & Total Biaya Penyusutan & $89.374,67$ \\
\hline
\end{tabular}

Biaya penyusutan merupakan biaya yang diperhitungkan dari nilai komponen alat dibagi dengan umur ekonomi alat yang digunakan dalam proses produksi, artinya alat yang digunakan ini setiap saat akan mengalami kehausan atau menyusut. Melihat data pada tabel 4 di atas total biaya penyusutan peralatan dalam proses produksi tempe sebesar Rp 109.374,67 dimana biaya penyusutan tertinggi ada pada mesin pemecah kulit sebesar Rp 25.000 berikutnya biaya penyusutan kelabang, panci,papan cetak dan bakul berkisar anta Rp 14.000 sampai dengan $\mathrm{Rp} 16.000$ dan biaya penyusutan terendah adalah penyusutan ember sebesar Rp 3.125

Selanjutnya biaya variabel yang dikeluarkan dalam proses produksi terdiri dari pembelian bahan baku kedelai , ragi, plastik, kayu bakar, bahan bakar minyak, iuran air/listrik, upah tenaga kerja dapat dilihat pada tabel 4 berikut :

Tabel 6. Biaya Variabel Industri pengolahan Tempe

\begin{tabular}{|l|l|r|}
\hline No & \multicolumn{1}{|c|}{ Jenis Biaya } & $\begin{array}{c}\text { Total Biaya (Rp) } \\
\text { TVC }\end{array}$ \\
\hline 1 & Bahan Baku Kedelai & 495.000 \\
\hline 2 & Ragi & 10.000 \\
\hline 3 & Plastik & 30.000 \\
\hline 4 & Kayu Bakar & 35.000 \\
\hline 5 & Bensin & 7.000 \\
\hline 6 & Iuran air/listrik & 17.000 \\
\hline 8 & Upah Tenaga Kerja & 120.000 \\
\hline & Total Biaya Variabel & 714.000 \\
\hline
\end{tabular}




\section{Elastisitas - Jurnal Ekonomi Pembangunan}

Vol. 2 No. 1, Maret 2020

Total biaya variabel sebesar Rp 714.000 terdiri dari pembelian bahan baku kedelai dalam sekali proses produksi sebanyak $50 \mathrm{Kg}$ dengan nilai beli $\mathrm{Rp}$ 495.000,- kemudian upah tenaga kerja sebesar Rp 120.000, pembelian kayu bakar Rp 35.000,- plastik putih bening daan warna kuning Rp 30.000 ,listrik,air $\mathrm{Rp} 17.000$,- ragi $\mathrm{Rp} 10.000$ dan BBM Rp 7.000,-

\section{A. Pendapatan dari Usaha Agroindustri Pengolahan Tempe}

Pendapatan merupakan selisih antara total nilai penjualan produk tempe dikurangi dengan seluruh biaya yang dikeluarkan dalam proses produksi. Penelitian ini menghitung semua komponen biaya yang dikeluarkan dalam sekali proses produksi sehingga akan diperoleh pendapatan dari pengusaha tempe yaitu :

Tabel 3. Nilai Produksi Agroindustri Pengolahan Tempe

\begin{tabular}{|l|l|r|c|c|}
\hline No & Jenis Produk & $\begin{array}{c}\text { Jumlah } \\
\text { (unit) }\end{array}$ & $\begin{array}{c}\text { Harga } \\
\text { Satuan } \\
\text { (Rp) }\end{array}$ & $\begin{array}{c}\text { Nilai } \\
\text { Produksi } \\
\text { (Rp) }\end{array}$ \\
\hline 1 & $\begin{array}{l}\text { Tahu ukuran } \\
\text { besar }\end{array}$ & 750 & 1.250 & 937.500 \\
\hline 2 & $\begin{array}{l}\text { Tempe : } \\
\text { - Ukuran 10 x } \\
\end{array}$ & 700 & 1.000 & 700.000 \\
& $\begin{array}{l}\text { 10 x 1 Cm } \\
\text { Ukuran 15,1 } \\
\text { x 9,5 x 2 Cm }\end{array}$ & 300 & 1.500 & 450.000 \\
\hline & $\begin{array}{l}\text { Total nilai } \\
\text { produksi tempe }\end{array}$ & & & \\
\hline
\end{tabular}

Nilai produksi merupakan perkalian antara jumlah ouput tempe dikalikan dengan harga yaitu tempe ukuran kecil $(10 \times 10 \times 1 \mathrm{Cm})$ sebesar 700 unit $\times \mathrm{Rp} 1.000=\mathrm{Rp}$ uran 700.000,- dan Tempe ukuran besar ( $15,1 \mathrm{x}$ 9,5 × $2 \mathrm{Cm}$ ) adalah sebesar 300 unit x Rp $1500=\operatorname{Rp} 450.000,-$

Jadi pendapatan dari usaha agroindustri pengolahan kedelai menjadi tempe adalah :

$\Pi=$ Nilai Produksi - (Biaya Variabel + Biaya Penyusutan alat)

Nilai tambah yang diberikan pada pengolahan kedelai menjadi produk tempe adalah sebesar Rp 346.625 , dalam sekali proses produksi

$$
\begin{aligned}
& =\operatorname{Rp} 1.150 .000-(\operatorname{Rp} 709.000+ \\
& \text { 89.374,67) } \\
& =\operatorname{Rp~1.150.000~-~Rp~798.374,67~} \\
& =\operatorname{Rp~351.625,33~}
\end{aligned}
$$

Perhitungan efisiensi usaha agroindustri pengolahan kedelai menjadi tempe dilakukan dengan menggunaka $\mathrm{R} / \mathrm{C}$ Rasio, yaitu perbandingan antara nilkai produksi dengan biaya total ( TR/TC ) yaitu :

$\mathrm{R} / \mathrm{C}$ Rasio $=1.150 .000 / 798.374,67 \rightarrow 1,43$

Dengan nilai $\mathrm{R} / \mathrm{C}$ Rasio sebesar 1,43 maka usaha industri pengolahan kedelai menjadi tempe layak untuk diusahakan.

\section{B. Perhitungan Nilai Tambah Agroindustri Pengolahan Kedelai menjadi Tempe}

Nilai Tambah yang dimaksudkan dalam penelitian ini adalah nilai tambah yang diperoleh dari pemanfaatan kedelai setelah diolah menjadi produk tempe yaitu dihitung dengan mengurangkan nilai produk dengan nilai bahan baku, nilai bahan penunjang dan nilai penyusutan peralatan. Selanjutnya baru dihitung rasio nilai tambah produksi tempe, secara rinci dapat dilihat pada tabel 5 berikut ini :

Tabel 5. Nilai Produksi, Bahan Baku, Bahan penunjang, Nilai Penyusutan Dan Nilai Tambah agroindustri Pengolahan Kedelai menjadi Tempe

\begin{tabular}{|l|l|c|}
\hline No & \multicolumn{1}{|c|}{ Uraian } & $\begin{array}{c}\text { Nilai ( Rp/Kg) } \\
\text { per proses } \\
\text { produksi }\end{array}$ \\
\hline 1 & Nilai Produksi & 1.150 .000 \\
\hline 2 & Nilai Bahan Baku Kedelai & 495.000 \\
\hline 3 & Nilai Bahan Penunjang & 219.000 \\
\hline 4 & Nilai Penyusutan & 89.375 \\
\hline $\mathbf{5}$ & Nilai Tambah & $\mathbf{3 4 6 . 6 2 5}$ \\
\hline $\mathbf{6}$ & Rasio Nilai Tambah & $\mathbf{3 0 , 1 5} \mathbf{( \% )}$ \\
\hline
\end{tabular}

Jadi besarnya Nilai Tambah sekali proses produksi :

$$
\begin{aligned}
\text { NTp }= & \operatorname{Rp~} 1.150 .000-(\operatorname{Rp} 495.000+ \\
& \operatorname{Rp} 219.000+\operatorname{Rp} 89.375) \\
= & 1.150 .000-803.375 \\
= & 346.625
\end{aligned}
$$

dengan menggunakan bahan kedelai sebanyak $60 \mathrm{Kg}$ atau rata-rata nilai tambah per $\mathrm{Kg}$ kedelai setelah di proses menjadi tempe 


\section{Elastisitas - Jurnal Ekonomi Pembangunan}

Vol. 2 No. 1, Maret 2020

sebesar Rp 5.777,--. Besarnya nilai tambah ini diperoleh dari pengurangan nilai output sebesar Rp 1.150.000 dengan biaya bahan baku (nilai bahan baku kedelai ) sebesar $\mathrm{Rp}$ 495.000,-( dengan harga kedelai impor Selanjutnya perhitungan rasio nilai tambah terhadap nilai outputnya yaitu diperoleh dari pembagian antara nilai tambah dengan nilai output yang dinyatakan dalam prosentase (\%). Secara matematis Rasio Nilai Tambah pada industri pengolahan kedelai menjadi produk tempe sebagai berikut :

$$
\begin{aligned}
\text { Rasio Nilai Tambah }= & \operatorname{Rp} 346.625 / \mathrm{Rp} \\
& 1.150 .000 \\
= & 30,15 \%
\end{aligned}
$$

Ini berarti Rasio Nilai Tambah produk olahan kedelai menjadi tempe masih tergolong rendah karena Rasionya masih lebih kecil ( < $50 \%$ ). Hal ini menunjukkan bahwa apabila hasil perhitungan Rasio Nilai Tambah $<50$ $\%$, maka ini berarti nilai tambah yang dihasilkan lebih kecil dari nilai outputnya , dan nilai tambahnya tergolong rendah.

\section{3) Proses Produksi Pengolahan Tahu}

Proses produksi dalam pembuatan tahu memakan waktu yang cukup panjang yaitu dimulai dari persiapan bahan baku kedelai, dimana dipilih kedelai yang kualitas bagus dan berbiji besar biasanya pengusaha tahu lebih banyak menggunakan kedelai impor impormasi pengusaha tahu Abian tubuh milik, $\mathrm{H}$. Mohamad Sarman sebagai subyek penelitian. Usia H. Mohamad Sarman kini menginjak usia 50 tahun dan Usaha pengolahan tahu ini sudah ditekuninya sejak 20 tahun yang diterima dari orang tuanya. Tahu Abian tubuh ini sangat terkenal dimasyarakat Kota Mataram bagi yang pecinta makanan tahu karena teksturnya yang putih tebal dan padat. Selain itu juga tahu Abiantubuh ini banyak dibeli sebagai oleh-oleh karena bentuk pisiknya tahan sampai dua hari dan apalagi direbus lagi dan masukkan kedalam kulkas bisa tahan sampai 5 hari. kisaran antara Rp 8000 sampai dengan Rp 8500 , jadi harga dalam perhitungan $\mathrm{Rp}$ $8.250 / \mathrm{Kg}$. ), dan biaya sumbangan input lain yaitu totalnya $\mathrm{Rp} 308.375$ yaitu terdiri dari nilai bahan penunjang dan nilai penyusutan.

\section{A. Biaya Penyusutan Agroindustri Pengolahan Tahu}

Peralatan yang digunakan dalam proses pengolahan kacang kedelai menjadi tahu memnggunakan berbagai macam peralatan yang mana peralatan tersebut sangat menentukan dalam tahapan produksi, misalnya tempat merendam kedelai, mesin penggilingan, kain penyaring, cetakan tahu, penyaringan, bak penampungan dan sendok pengaduk. Berikut jenis peralatan dan nilai peralatan yang digunakan dalam sekali proses produksi agroindustri pengolahan tahu milik H.Mohaman Sarman di Abian tubuh sebagai berikut :

Tabel 6. Biaya Penyusutan Peralatan Usaha Pengolahan Tahu

\begin{tabular}{|c|l|r|}
\hline No & \multicolumn{1}{|c|}{ Jenis Peralatan } & $\begin{array}{c}\text { Nilai Penyusutan } \\
\text { (Rp ) }\end{array}$ \\
\hline 1 & Mesin Penggilingan & $25.000,00$ \\
\hline 2 & Jambangan besar & $16.666,67$ \\
\hline 3 & Ember & $15.277,78$ \\
\hline 4 & Kain Saringan & $15.000,00$ \\
\hline 5 & Penyaring & $12.500,00$ \\
\hline 6 & Cetakan Tahu & $15.000,00$ \\
\hline 7 & Pisau & 416,67 \\
\hline 8 & Ayakan & $10.666,67$ \\
\hline 9 & Kain cetak & $10.000,00$ \\
\hline 10 & Bak Penampungan & $16.666,67$ \\
\hline 11 & Drim Uap & $16.666,67$ \\
\hline 12 & Sendok Pengaduk & $1.388,89$ \\
\hline & Total Biaya Penyusutan & $155.416,69$ \\
\hline
\end{tabular}

Biaya penyusutan pemakaian peralatan dalam sekali proses produksi pengolahan kedelai menjadi tahu pada tabel 6 di atas, yaitu mesin penggilingan Rp 25.000 jambangan besar Rp 16.667,67 kemudian ember, kain saringan, cetakan tahu,bak penampungan dan drim uap rata-rata nilai penyusutannya kisaran antara Rp $\quad 15.000$ sampai dengan $\mathrm{Rp} \quad 17.000$ selanjutnya nilai penyusutan kain cetak, ayakan, dan penyaring berkisar antara $\mathrm{Rp}$ 10.000 sampai dengan Rp 12.500 dan niali 


\section{Elastisitas - Jurnal Ekonomi Pembangunan}

Vol. 2 No. 1, Maret 2020

penyusutan alat yang terendah yaitu sendok pengaduk Rp 1.388,89 dan pisau Rp 416,67.

\section{B. Biaya-Biaya Variabel dalam sekali proses produksi.}

Besar kecilnya pendapatan usaha yang diterima pemilik usaha sangat ditentukan oleh besar kecilnya pengeluaran untuk biaya produksi sebab biaya produksi menyangkut keseluruhan biaya yang dikeluarkan mulai dari tahapan awal sampai pada tahapan akhir dalam kegiatan pembuatan tahu. Prinsipnya apabila pemilik usaha dapat menekan biayabiaya produksiseefisien mungkin, maka akan memperbesar perolehan pendapatan yang diterima pengusaha tahu . Biaya produksi dalam agroindustri pengolahan kedelai menjadi tahu diperhitungkan dalam sekali proses produksi yang dikeluarkan termasuk biaya tenaga kerja dan pembelian bahan baku utama dan bahan baku penolong. Berikut rincian biaya-biaya yang dikeluarkan dalam usaha pengolahan kedelai menjadi tahu dalam sekali proses produksi, sebagai berikut :

Tabel 7. Biaya Variabel Usaha Pengolahan

\begin{tabular}{|c|c|c|}
\hline No & Jenis Biaya & $\begin{array}{l}\text { Total Biaya } \\
\text { (TVC) (Rp) }\end{array}$ \\
\hline 1 & Bahan Baku Kedelai & 400.000 \\
\hline 2 & Garam & 15.000 \\
\hline 3 & Kayu bakar & 25.000 \\
\hline 4 & Kulit kacang & 7.500 \\
\hline 5 & Bensin & 7.000 \\
\hline \multirow[t]{2}{*}{6} & Upah tenaga kerja & 100.000 \\
\hline & Total Biaya Variabel & 554.500 \\
\hline
\end{tabular}

Pengeluaran biaya-biaya agroindustri pengolahan kedelai menjadi tahu yang dikeluarkan dalam sekali proses produksi terdiri dari biaya pembelian bahan baku utama kedelai sebesar Rp 400.000 atau sekitar $72,14 \mathrm{v} \%$ dari total biaya, kemudian biaya bahan penolong terdiri dari garam,kayu bakar, kulit kacang dab BBM totalnya sebesar Rp 54.500 atau sebesar $9,83 \%$ dari total biaya produksi dan biaya untuk upah tenaga kerja ( 2 orang ) sebesar Rp
$100.000,-$ atau sebesar 18,03 dari total biaya produksi.

Nilai produksi merupakan perkalian antara harga produk dengan jumlah produk tahu yang dihasilkan dalam sekali proses produksi , dimana hasil produksi pengolahan kedelai menjadi tahu dalam sekali proses produksi menghasilkan 30

cetakan tahu. Harga percetakan tahu sebesar Rp 35.000 sehingga pendapatan kotor (Total Revenue/TR) yang diterima dalam sekali proses produksi dalam pengolahan tahu adalah sebesar :

$$
\begin{aligned}
\mathrm{TR} & =\mathrm{p} \times \mathrm{q} \\
& =30 \times \mathrm{Rp} 35.000 \\
& =1.050 .000
\end{aligned}
$$

\section{Analisis Pendapatasn}

Pendapatan yang diterima oleh pengusaha tahu di Abiantubuh merupakan selisih antara pendapatan kotor (TR) dikurangi dengan total biaya variabel dan total biaya penyusutan. Ataui dalam formulasi menghitung pendapata bersih adalah sebagai berikut :

$$
\begin{aligned}
& \Pi=\mathrm{TR}-\mathrm{TC} \\
& \mathrm{TC}=\mathrm{TVC}+\mathrm{TFC} \\
& \pi=\operatorname{Rp~} 1.050 .000-(\operatorname{Rp} 554.500+\mathrm{Rp} \\
& \text { 155.416, 67) } \\
& =\operatorname{Rp~1.050.000-Rp~709.916,67~} \\
& =\operatorname{Rp~340.083,33~atau~Rp~340.000,-~}
\end{aligned}
$$

\section{Analisis Efisiensi Usaha Agroindustri Pengolahan Tahu}

Efisiensi merupakan suatu ukuran keberhasilan yang dinilai dari segi besarnya sumber atau biaya untuk mencapai hgasil dari kegiatan yang dilakukan atau dijalankan oleh penggiat usaha. Untuk mencapai suatu tingkat efisiensi maka penggunaan seluruh sumberdaya yang ada digunakan sedikit mungkin untuk mencapai hasil yang diharapkan dengan tanpa mengurangi ukuran dan kualitas, maka proses penggunaan biaya ini dikatakan semakin efisien.

Efisiensi usaha merupakan perbandingan anatara total pendapatan kotor (TR) dengan 


\section{Elastisitas - Jurnal Ekonomi Pembangunan}

Vol. 2 No. 1, Maret 2020

total biaya produksi (TC), yang biasa dirumuskan dengan $\mathrm{R} / \mathrm{C}$ Rasio atau $\mathrm{R} / \mathrm{C}$

$$
\begin{aligned}
\text { Rasio } & =\mathrm{TR} / \mathrm{TC} \text { atau } \\
& =1.050 .000 / 709.916,67 \\
& =1,47
\end{aligned}
$$

Dengan nilai $\mathrm{R} / \mathrm{C}$ Rasio sebesar 1,47 maka usaha agro industri pengolahan kedelai menjadi tahu layak untuk diusahakan.

\section{E. Perhitungan Nilai Tambah Agroindustri Pengolahan Kedelai menjadi Tahu}

Nilai Tambah yang dimaksudkan dalam penelitian ini adalah nilai tambah yang diperoleh dari pemanfaatan kedelai setelah diolah menjadi produk tahu yaitu dihitung dengan mengurangkan nilai produk dengan nilai bahan baku, nilai bahan penunjang dan nilai penyusutan peralatan. Selanjutnya baru dihitung rasio nilai tambah produksi tempe, secara rinci dapat dilihat pada tabel 8 berikut ini :

Tabel 8. Nilai Produksi, Bahan Baku, Bahan penunjang, Nilai Penyusutan Dan Nilai Tambah agroindustri Pengolahan Kedelai menjadi Tahu

\begin{tabular}{|r|l|r|}
\hline No & \multicolumn{1}{|c|}{ Uraian } & \multicolumn{1}{|c|}{$\begin{array}{c}\text { Nilai ( Rp/Kg) } \\
\text { per proses } \\
\text { produksi }\end{array}$} \\
\hline 1 & Nilai Produksi & 1.050 .000 \\
\hline 2 & $\begin{array}{l}\text { Nilai Bahan Baku } \\
\text { Kedelai }\end{array}$ & 400.000 \\
\hline 3 & Nilai Bahan Penunjang & 54.500 \\
\hline 4 & Nilai Penyusutan & $155.416,69$ \\
\hline 5 & Nilai Tambah & $\mathbf{4 4 0 . 0 8 3 , 3 1}$ \\
\hline 6 & Rasio Nilai Tambah & $\mathbf{4 1 , 9 1 \quad ( \% )}$ \\
\hline
\end{tabular}

Jadi besarnya Nilai Tambah sekali proses produksi :

$$
\begin{aligned}
\mathrm{NTp}= & \operatorname{Rp} 1.050 .000-(\operatorname{Rp} 400.000+\mathrm{Rp} \\
& 155.416,67+\operatorname{Rp} 54.500) \\
= & 1.150 .000-609.916,69 \\
= & 440.083,31
\end{aligned}
$$

Nilai tambah yang diberikan pada pengolahan kedelai menjadi produk tempe adalah sebesar Rp 440.083,31, dalam sekali proses produksi dengan menggunakan bahan kedelai sebanyak $50 \mathrm{Kg}$ atau rata-rata nilai tambah per $\mathrm{Kg}$ kedelai setelah di proses menjadi tempe sebesar Rp 5.777. Besarnya nilai tambah ini diperoleh dari pengurangan nilai output sebesar $\mathrm{Rp} 1.050 .000$ dengan biaya bahan baku (nilai bahan baku kedelai ) sebesar Rp 400.000 (dengan harga kedelai impor kisaran antara Rp 8000, dan biaya sumbangan input lain yaitu totalnya $R p 209.916,67$ yaitu terdiri dari nilai bahan penunjang dan nilai penyusutan.

Perhitungan rasio nilai tambah terhadap nilai outputnya yaitu diperoleh dari pembagian antara nilai tambah dengan nilai output yang dinyatakan dalam prosentase $(\%)$. Secara matematis Rasio Nilai Tambah pada industri pengolahan kedelai menjadi produk tempe sebagai berikut :

$$
\begin{aligned}
& \text { Rasio Nilai Tambah }=R p \text { 440.083,69 / Rp } \\
& 1.050 .000 \\
& =41,91 \%
\end{aligned}
$$

Rasio Nilai Tambah sebesar 41,91\% hal ini menunjukkan bahwa apabila hasil perhitungan Rasio Nilai Tambah $<50 \%$, maka ini berarti nilai tambah yang dihasilkan lebih kecil dari nilai outputnya, dan nilai tambahnya tergolong rendah.

\section{KESIMPULAN}

Hasil penelitian menunjukkan bahwa Usaha industri kerupuk kulit Ud. Shinta dalam sekali proses produksi usaha agroindustri pengolahan kerupuk kulit memperoleh pendapatan sebesar $\mathrm{Rp} 3.254 .750$ dengan menggunakan bahan baku kulit sebanyak 100 Kg. Sedangkan Efisiensi usaha atau R/C Rasionya sebesar 1,78 , berarti usaha industri pengolahan kulit sapi menjadi kerupuk kulit menguntungkan untuk diusahakan. Besarnya Nilai Tambah usaha kerupuk kulit sapi yaitu sebesar Rp 54.641,79 artinya bahwa setiap 1 $\mathrm{Kg}$ kulit sapi yang diolah menjadi kerupuk kulit sapi dapat memberikan penambahan nilai sebesar $\mathrm{Rp}$ 54.641,79. Rasio Nilai Tambah (RNT) pada industri pengolahan kerupuk kulit sapi sebesar 50,53\%, artinya bahwa nilai tambahnya tergolong tinggi karena rasionya lebih besar dari $50 \%$ ( RNT 


\section{Elastisitas - Jurnal Ekonomi Pembangunan}

Vol. 2 No. 1, Maret 2020

$>50 \%$ ). Hal yang sama pada industri pengolahan kedelai menjadi tempe di Gerisak Kekalik dimana pendapatan yang diperoleh sebesar $\mathrm{Rp}$ 351.625,33 dengan tingkat efisiensinya $(\mathrm{R} / \mathrm{C}$ Rasio $=1,43)$, sehingga usaha industri pengolahan tempe layak untuk diusahakan. Rasio Nilai Tambah (RNT) sebesar 30,15\%, ini berarti rasio nilai tasmbah produk olahan kedelai menjadi tempe masih tergolong rendah karena nilai rasionya masih dibawah 50\% (RNT < 50\%). Selanjutnya pendapatan yang diperoleh usaha industri pengolahan kedelai menjadi tahu di Abiantubuh sebesar Rp 340.000 dengan tingkat efisiensi usaha sebesar 1,47 (R/C Rasionya $=1,47$ ) artinya usaha agroindustri pengolahan kedelai menjadi tahu layak untuk diusahakan. Sedangkan Rasio Nilai Tambah (RNT) nya sebesar 41,91\%, hal ini menunjukkan bahwa nilai tambah yang dihasilkan usaha pengolahan kedelai menjadi tahu tergolong rendah karena RNT nya berada dibawah $50(\mathrm{RNT}<50 \%)$.

Agroindustri pengolahan kulit sapi diupayakan untuk mengembangkan produk nya agar lebih inovatif baik dari rasa maupun kemasan produknya. Selanjutnya untuk agroindustri pengolahan tempe dan tahu agar lebih menekan biaya-biaya produksi guna meningkatkan nilai tambah serta lebih meningkatkan mutu dan kualitas produknya agar bisa bertahan lama di pasaran, artinya produk tempe dan tahu ini tidak mudah rusak.

\section{DAFTAR PUSTAKA}

2013. Dinas Tenaga kerja Kota Mataram

Arikunto, Suharsini. 2006. Prosedur Penelitian. Suatu pendekatan Praktik. PT. Reneka Cipta. Jakarta

Aryo Demarto,dkk.2003. Sektor informal alternatip kesempatan kerja Bagi Golongan Berpendidikan Rendah. Makalah Diklat Universitas Sebelas Maret.

Kartasasmita M. 2011. Pengertian Agroindustri . Blokspot.com. 2011

Mubyarto.1998. Konsep Biaya Industri Kecil. Gramedia Jakarta

Nasir, Mohammad. 2009. Metode Penelitian. Graha Indonesia. Jakarta.

Putong Iskandar. 2002. Pengantar Ekonomi Mikro dan Makro. Galia Indonesia

Santri Y,M. 2009. Analisis Usaha Agroindustri Keripik Belut di Kabupaten Klaten. Program Studi Agribisnis Fakultas Pertanian Universitas Sebelas Maret Surakarta.

Sudiyono. 2004. Pemasaran Pertanian. UMM. Malang

Sukartawi. 2003. Agribisnis. Teori dan Aplikasinya. PT. Raja Grafindo Persada Jakarta. 